\title{
The mediating role of test anxiety and cooperation in the relationship between motivation and reading comprehension *
}

\author{
Çağla Alpayar, Ankara University, Turkey, alpayar@ankara.edu.tr, ORCID: 0000-0003-3178-5560 \\ İlke Altuntaş Gürsoy, The Gendarmerie and Coast Guard Academy, Turkey, bjk ilke1903@hotmail.com, \\ ORCID: 0000-0003-1394-5778
}

\begin{abstract}
The purpose of this study is to construct a model that tests the mediating effects of test anxiety and cooperation on the relation between motivation and reading comprehension. The study was carried out within the framework of predictive correlational design. The sample consisting of 1562 students was randomly selected from Turkey sample of the PISA 2015. Structural equation modeling was performed to test the hypothesis about direct and indirect relations between the defined variables. The results showed that test anxiety and cooperation had a partial mediating effect on the relation between motivation and reading comprehension. When the direct relations examined, it was found out that there is a positive and significant relation between motivation and reading comprehension. On the other hand, there is a positive and significant relation between the students' tendency to cooperation and reading comprehension while the relation between test anxiety and reading comprehension is significant and negative.
\end{abstract}

Keywords: PISA 2015, Reading Comprehension, Motivation, Test Anxiety, Cooperation

Received: 02.05.2020

Accepted: 17.08 .2020

Published: 01.12.2020

\section{INTRODUCTION}

Reading is a crucial life skill for individuals. Without the development of this skill, it would not be possible to understand the events occurred in society, to associate them, to judge them by thinking and to find a solution (Kutlu, 2004). Sellers (2000) states that reading has a complex nature and a difficult process because readers need to coordinate attention, perception, memory, and comprehension. It is to comprehend and internalize the written text, its concept, its fiction, its language and its expressions. At the same time, reading is a memory activity that requires the perception of the concept design process, the execution of the cognitive processes and the completion of the process of meaning. Ünalan (2006) defines reading as a process of perceiving and perceiving words, sentences, writing as a whole. Similarly, Duke and Carlisle (2011) define comprehension as "the act of constructing meaning with the oral or written text. This is truly a constructive process". Based on these definitions, it cannot be said that a reading activity is successful unless it results in understanding.

Reading is a dynamic construction process of meaning that requires an effective and active communication between a reader and a writer (Akyol, 2006). It is an effective interaction (Göktürk, 1989) and as the result of this interaction, reading comprehension is constructed. The writer is both a writer and a reader. The actual reading is to read as a writer. By the author's editorial language, it enables the reader to enter other environments with the level of appreciation he has created (Binyazar, 2010). Readers also receive the text depending on their own cognitive and affective characteristics, word perspective, and aesthetic taste and thus participate in the production process and recreate the text depending on their own individual position, emotional and intellectual nature (Göktürk, 2002). Similarly, Sever (2004) emphasizes that reading is a development process with cognitive, emotional and kinesthetic dimensions. In other words, reading is a complicated process that is affected by the individual's characteristics (Rand Reading Study Group, 2002). The reader's affective characteristics are as crucial as his cognitive features during the construction of reading. Therefore, it is necessary to have not only

\footnotetext{
${ }^{*}$ This study was presented at the 3rd International Contemporary Educational Research Congress (June 5-8, 2018)
} 
cognitive, but also affective competencies. the students' thinking and interpretation power develop, they gain feeling of well-being and appreciation, and begin to perceive national and universal cultural accumulation as they develop their reading skills (Aslanoğlu, \& Kutlu, 2015). Reading skill contributes to the intellectual and emotional development and the educational development of individuals by improving their empathy and creative thinking (Kutlu, Altıntaş, Özyeter, Alpayar, \& Kula Kartal, 2019). This leads researchers to examine the social, motivational, and affective underpinnings of reading beyond the cognitive dimensions (Baker, Afflerbach, \& Reinking, 1996). The reader's characteristics such as interest, anticipation, need, anxiety, motivation, the tendency to cooperation without working individually or competitively are crucial in this direction.

As in the last Turkish Course Instructional Program (Ministry of National Education, [MoNE], 2019), it is aimed to develop students' skills of researching, discovering and interpreting knowledge, then restructuring it in their mind. Another purpose of Turkish Instructional Program is to ensure that the students evaluate their reading from a critical perspective. The purpose of this language skill training is to ensure that students understand their reading and gain reading habits. It is aimed to develop reading skills by taking into account the cognitive skills as well as the affective skills such as co-operation, respect for people around, active participation in activities and effort in terms of the program (MoNE, 2019). Therefore, as the purpose of Turkish education is to improve the reading skills and cognitive skills as well as various affective skills, the determination of their development level is important.

One of the tools used to evaluate the effectiveness of instructional programs on the international scale is the International Student Assessment Program (PISA). PISA is designed to assist governments in monitoring the outcomes of education systems in terms of student achievement on a regular basis and within an internationally accepted common framework (Thomson, Hillman, \& Bortolli, 2013). This research project conducted by the Organization for Economic Cooperation and Development (OECD) provides a common task to compare the students from the participating countries and a general performance of students from the same country. Reading comprehension by the name of "Reading Literacy" takes place among the cognitive assessment fields measured by the achievement tests. Within the scope of PISA, reading literacy is defined as understanding, using, reflecting on and engaging with written texts, in order to achieve one's goals, to develop one's knowledge and potential, and to participate in society (OECD, 2017). In PISA studies, in addition to the achievement tests including the PISA reading test, different questionnaires are also applied to find out the effective factors on the students' achievement levels. One of them is the Student Questionnaire. This questionnaire provides information about various student characteristics. In this direction, questionnaire materials aiming to determine the level of having various characteristics within the scope of the PISA 2015 study was also applied to 15-year-old students. Test anxiety (ANXTEST), motivation (MOTIVAT) and tendency to cooperation (COOPERATE) are among the affective characteristics taking place in the PISA 2015 study as probably related factors with students' reading comprehension skill.

Motivation is one of the capabilities and abilities that affect the reader's comprehension (Rand Reading Study Group, 2002). From the educational perspective, motivation is defined as a derivation, a desire or an emotion to learn. Dweck (1975) stated that the motivation caused the students to afford more and engaged them in remedial actions even when he faced the failure. Similarly, Guthrie (2004) explains the relation between motivation and reading comprehension under the mediation of the engagement. If motivation for reading is not sufficient, it will not take as much time as necessary to read (Baker, \& Wigfield, 1999; Wigfield, Guthrie, Tonks, \& Perencevich, 2004). And this will affect the comprehension process. The motivation and the interest level of the reader affect reading comprehension both directly and indirectly (Kintsch, \& Kintsch, 2005). Similarly, Akyol (2012) states that motivation, one of the affective characteristics having an effect on the reading comprehension, has a key role in improving reading; therefore, it should be emphasized carefully.

According to the researcher, the engaged readers want to learn, take satisfaction in successful reading, and believe in their reading skills. The students who are motivated in such a way are expected to persist in their study despite the difficulties until they reach their goals. It is 
stated that when children have internal or external motivation for a specific purpose, they participate in activities. However, when students do not have sufficient motivation, they do not even participate in the activities they are good at (Wigfield \& Guthrie, 1997). In a more specific meaning, the motivated students make more effort to understand the text and complete the task related to it. Similarly, Guthrie, Hoa, Wigfield, Tonks, Humenick, and Littles (2007) describe the motivation of reading as a multi-level structure that includes various variables such as selfefficacy, interest, openness to cooperation. They state this variable as an important predictor of reading skill. From this perspective, it could be stated that if the students are motivated readers and willing to learn; they take satisfaction in successful reading, and believe in their reading skills. Importantly, they persist in the face of difficulty and exert continuing effort until they have attained their goals for understanding a passage or have completed a portion of a project. Therefore, other affective characteristics related to reading comprehension would be examined as stemming from motivation. In this regard, it can be said that the experiences gained from the family and the environment of the student can change their judgements about reading by turning into attitudes over time. Because the individual cannot be considered in isolation from the society. The socio-cultural and economic condition of the environment they live in and the school they attend will also affect their motivation to read. The behavior of teachers at school, their attitudes towards students together with the administrators and the curriculum implemented according to the type of the school can also affect motivation. Wang \& Guthrie (2004) stated that the cultural accumulation and judgements acquired during the learning process are known to affect motivation.

One of the affective features of the reader and possible mediating variable between motivation and reading comprehension is the tendency to cooperation. Johnson and Johnson (1999) clarify the features of cooperative people. According to the researchers, the cooperative people strive for everyone's success rather than for only their own success, perceive the joint success to be celebrated and help others to learn. They perceive that what benefits themselves also benefits others. According to Kouros and Abrami (2006) asking for help from each other, sharing information with others to complete the task and even joking, encouraging the collaboration are among the cooperative behaviors. In PISA 2015 "perceiving others' perspective" is an investigator of the tendency to cooperation. There is a relation between empathy and collaboration. In their studies, Marcus, Tellen, and Roce mention about the relation between the ability of empathy and collaboration (as cited in Dinçyürek, 2004). Similarly, in a study it is concluded that the children with the high ability of empathy are more prone to be in cooperation with their friends and have stronger social relationships (Strayer, \& Robert, 2004). Briefly, empathy may be defined as the ability to put oneself imaginatively in another's place (Rogers, 1983; Trans. Akkoyun). Therefore, if someone has the ability to put himself/herself in another's place, he/she is prone to collaboration. The relationship between empathy and collaboration indicates the relationship with reading comprehension skills. As stated before, the readers make sense of what the writer put forward and reconstruct the text in their brain to comprehend it; to reconstruct the text, the readers need to understand the writer's perspective by means of their knowledge. If the readers could make the connection between the text and their knowledge of the world, their reading comprehension skills develop (Anderson, \& Pearson, 1984).

One of the affective characteristics that might have a mediating effect on reading comprehension and motivation is test anxiety. Test anxiety is a form of anxiety concerning apprehension over academic evaluation that comes from the fear of failure (Horwitz, \& Young, 1991). The researchers explain the relationship between test anxiety and test performance in two ways. Some researchers examine the concern caused by test anxiety has an interference effect on the attention and the test performance. Eysenck and Calvo (1992) explain the relation between test anxiety and test performance based on the working memory capacity. High test-anxious individuals concern about results of the test and personal inefficacy. These thoughts would decrease the working memory capacity, interference with the cognitive process of answering the test and therefore affect the test performance negatively. The results from many studies support the adverse relation between test anxiety and comprehension (Katrancl, \& Kuşdemir, 2016; Wood, Hart, Little, \& Philips, 2016; Yamaç \& Sezgin, 2018). On the other hand, test anxiety has an 
impulsive effect on the students and lead them spending more afford to avoid the failure and this effort would compensate the decrease in the working memory capacity and inference (Calvo, Ramos, \& Estevez, 1992). Therefore, according to the results of some studies, there is no relation (Javabakht, \& Hadian, 2014) or insignificant relation (Birjandi, \& Alemi, 2010) between their test anxiety and performance in language tests. The studies in the literature support the combination of motivation and test anxiety is related to the students' performance especially when the stake is high (Horwittz, 2001; Noels, Pelletier, Clement, \& Vallerand, 2000). This similar to the classroom assessment (Hancock, 2001). As the result of the study, the more test anxious students are, the poorly they perform and less motivated they become. Motivation and the test anxiety interacted with personal factors and social contextual and leading to performance differences across the three testing contexts (Cheng, Klinger, Fox, Jin \& Wu, 2014). In the literature there are some implications that anxiety affects reading comprehension, in this way it affects academic success as well. According to Campbell (1986; as cited in Yurttaş, 2018) the students have difficulty in reading comprehension when they experience test anxiety. In that case, the relationship between reading comprehension and anxiety draws attention.

In the literature, there are not any studies within which mediating roles of test anxiety and reading comprehension on the relationship between motivation and reading comprehension. Within this study, those affective characteristics and the relations between them were examined together around the focus of reconstructing the meaning from the text. A model to test the assumptions related to the relations between the stated characteristics and the direction of the relations were determined based on the findings of the previous studies. The general assumption was that the more the students were motivated, the more they were capable of handling the test anxiety arising from fear of failure and more open to cooperation and understand others' perspective; as a result, such students are capable of comprehending. Findings of the study could reveal the level of both affective characteristics and cognitive skills that students are intended to gain in the Turkish Course Instructional Program. Moreover, the level relations between affective characteristics and reading comprehension could be found out. According to the findings, suggestions for the curriculum development, the relevance of the updating work, and classroom activities could be planned. All in all, the aim of this study is to relate some of the students' affective characteristics and their reading comprehension level based on results of the PISA 2015 study in Turkey. In the light of the above statements, it is seen as a necessity to examine the relations between some of the students' affective characteristics and their reading comprehension level. For this purpose, the following research questions were investigated:

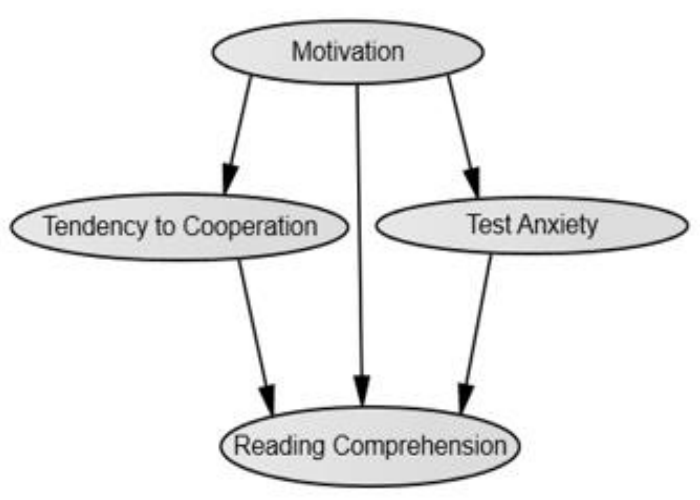

Figure 1. The Proposed Structural Model
1. Is there a statistically significant relationship between students' reading comprehension skill and

1.1. Motivation?

1.2. Test Anxiety?

1.3. Tendency to cooperation?

2. Is there a statistically relationship between students' motivation and

2.1. Test anxiety?

2.2. Tendency to cooperation?

3. Is the mediating effect of cooperation on the relationship between reading comprehension and motivation significant?

4. Is the mediating effect of test anxiety on the relationship between reading comprehension and motivation significant? 


\section{METHODS}

\section{Research Design}

The study that aims to investigate the relationship between test anxiety, motivation, tendency to cooperation and reading comprehension was conducted based on a predictive correlational research design. In correlational research, the relationships between two or more variables are explored and no manipulation is made on the variables (Fraenkel, Wallen, \& Hyun, 2012). In a predictive correlational design, the researcher tries to predict the output using some variables as a predictor rather than associating two variables in a simple way. For this reason, the investigator identifies one or more dependent and independent variables (Creswell, 2012).

\section{Participants}

The sample of the study was made up of PISA 2015 Turkey sample who were aged between 15 year 3 months and 16 years 2 months. The participants of PISA 2015 were selected by stratified sampling method. Turkey was stratified into 12 regions and 61 public or private schools were selected from the regions so that the probabilities of the schools were proportional to their size. Among the students from the schools, participants were randomly selected (Taş, Arıcı, Özarkan, \& Özgürlük, 2016). Finally, 5895 students were selected for the Turkish sample of PISA 2015. Working on excessively large samples beyond what is required to achieve statistical power are a waste of research effort and may overestimate their insignificant effects (Barker, Pistrang, \& Elliott, 2015; Cohen, 1990). Therefore, 30\% of the sample was randomly selected to perform the analysis.

\section{Data Analysis}

Within the aim of the study, a structural equation model has been constructed by data. Before the construction of the model, some assumptions were checked (Çokluk, Şekercioğlu, \& Büyüköztürk, 2012; Tavşancll, 2005; Tabachnick, \& Fidell, 2007). Firstly, the outliers were examined. $\mathrm{Z}$ transformation was executed and the data whose $\mathrm{z}$-values were out of the range between -3 and +3 were deleted from the data set. Secondly, the ratio of missing value in the data set was checked. As the ratio was lower than $\% 10$ of the data, the listwise deletion was executed. Mahalanobis distances were examined to see multivariate extreme values. As a result of the examinations, 207 cases were discarded and the sample was composed of 1562 cases. In addition, skewness and kurtosis of the total scores of the scales to see the univariate normality coefficients were examined (Table 1). In the literature, the skewness and kurtosis coefficient for social sciences is -2 and +2 are considered sufficient for normal distribution (Bryne, 2010; Hair, Black, Babin, \& Anderson, 2010).

Table 1. Descriptive Statistics of Variables

\begin{tabular}{lcccc}
\hline Variable & Mean & Std. Dev. & Skew & Kurtosis \\
\hline Motivation & 16.917 & 3.041 & -1.575 & 3.372 \\
Test Anxiety & 12.335 & 2.146 & -0.382 & -0.102 \\
Cooperation & 14.006 & 3.550 & -0.874 & 1.884 \\
Reading Comprehension & 430.277 & 72.899 & -0.001 & -0.211 \\
\hline
\end{tabular}

Thus, the data are considered to meet the normality assumption, the correlations between all the variables were examined $\left(r_{(\text {mot,test anx })}=0.256, r_{(\text {mot,cooperation })}=0.349, r_{(\text {mot }, \text { read })}=0.132\right.$, $\left.r_{(\text {test anx,cooperation })}=0.115, r_{(\text {test anx,read })}=-0.28, r_{(\text {cooperation, } r e a d)}=0.217, p<0.01\right)$. All the relationships were statistically significant and below 0.80 . Therefore, the data did not show multicolinnearity problems (Çokluk, Büyüköztürk, \& Şekercioğlu, 2012). Finally, the assumption 
of multivariate normal distribution was satisfied because the Mahalanobis distances were below the critical value of the proposed model which is 16.27 for 3 dependent variables (Pallant, 2013).

\section{RESULTS}

The assumptions were satisfied; therefore, the Structural Equation Model was constructed. The sample size is large enough and the multivariate normal distribution was satisfied. Therefore, Maximum Likelihood Estimation Method was executed. The main advantage of Maximum Likelihood Estimation Method is that the estimations by this method which is independent from scale and standard errors are unbiased as long as the normality assumption is satisfied and the sample size is large enough (Çelik \& Yllmaz, 2013).

\section{Measurement Model}

As the first step of testing the model constructed to explain the students' reading comprehension skill related to their affective characteristics, the measurement models of each latent variables by its observed variables were tested. To determine the internal consistency for the latent variables, the Cronbach Alpha Coefficients were calculated. The calculated reliability coefficients were between 0.982 (for Reading Comprehension) and 0.805 (for Tendency to Cooperation). Based on the Nunally's (1978) statements, the reliability coefficient should be higher than 0.80 . Therefore, the results related to internal consistency were acceptable.

The measurement model was tested before testing the structural model in accordance with Anderson and Gerbing's (1988) recommendations. The model test was performed using the AMOS program (Arbuckle, 1997), which uses the maximum likelihood (ML) method to examine the overall compatibility of the models to the corresponding observed variance-covariance matrices. Any modification process was not conducted because all the latent variables were predefined within PISA 2015 Students Survey and the latent constructs were tested whether they worked as they were defined.

The items from related scales constructing each measurement model of Motivation, Test Anxiety and Cooperation. The measurement model of Reading Comprehension was constructed by the plausible values of Reading Scores. The measurement models constructed by relations between latent variables and its observed variables with regard to standardized path coefficient As the first step of testing the model constructed to explain the students' reading comprehension skill related to their affective characteristics, the measurement models of each latent variables by its observed variables were tested. To determine the internal consistency for the latent variables, the Cronbach Alpha Coefficients were calculated. The calculated reliability coefficients were between 0.982 (for Reading Comprehension) and 0.805 (for Tendency to Cooperation). Based on the Nunally's (1978) statements, the reliability coefficient should be higher than 0.80 . Therefore, the results related to internal consistency were acceptable.

Table 2. The results of testing measurement models

\begin{tabular}{lccccccc}
\hline & $\begin{array}{c}\text { Standard } \\
\text { Value }\end{array}$ & Estimate & $\begin{array}{c}\text { Standard } \\
\text { Error }\end{array}$ & $\begin{array}{c}\text { Critical } \\
\text { Ratio }\end{array}$ & $\mathbf{p}$ & $\boldsymbol{R}^{\mathbf{2}}$ & Cronbach \\
\hline IMotivation & & & & & & & \\
\hline $\begin{array}{l}\text { SR119Q01 } \\
\begin{array}{l}\text { I want top <grades> in most or all } \\
\text { of my courses. }\end{array}\end{array}$ & 0.862 & 1.000 & & & & 0.516 & \\
$\begin{array}{l}\text { ST119Q02 } \\
\begin{array}{l}\text { I want to be able to select from } \\
\text { among the best opportunities } \\
\text { available when I graduate. }\end{array}\end{array}$ & 0.850 & 0.960 & 0.025 & 38.812 & $* *$ & 0.167 & 0.847 \\
$\begin{array}{l}\text { ST119Q03 } \\
\text { I want to be the best, whatever I do. }\end{array}$ & 0.662 & 0.878 & 0.031 & 28.180 & $* *$ & 0.439 & \\
\hline
\end{tabular}

(continued) 
Table 2. (Continued)

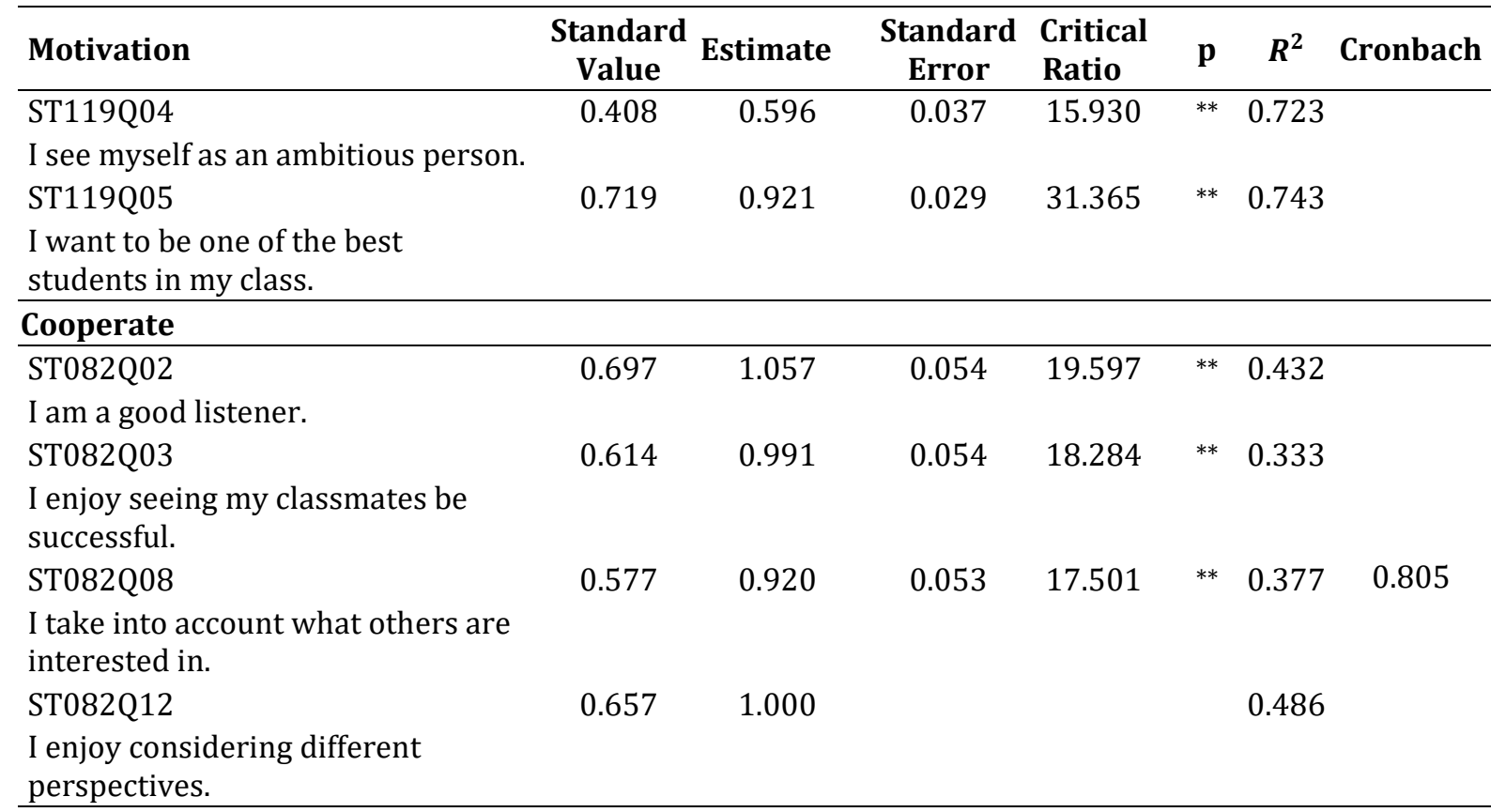

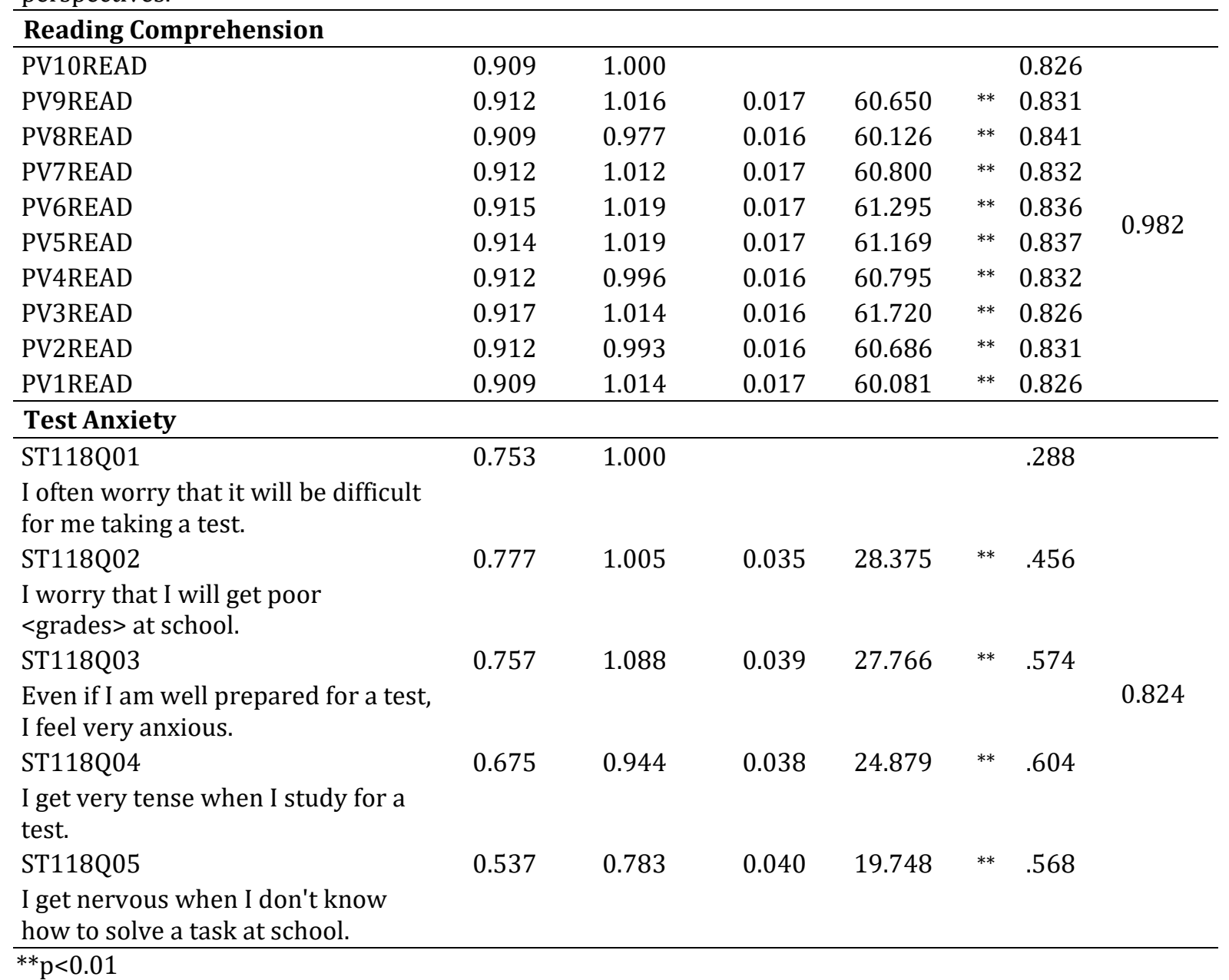

As seen in the Table 1, all the relations between the latent and its related observed variables were statistically significant. The measurement model was fit to the data and resulted in the following reasonable fit indices $\left(\chi_{(245)}^{2}=764.2, p<0.05 ;\right.$ CFI $=0.978, \quad N F I=0.978$, 
RMSEA=0.041, SRMR=0.0476, GFI=0.962, AGFI=0.954) (Hu, \& Bentler, 1999; Kline, 2005; Tabachnick \& Fidell, 2007). Therefore, the measurement model was confirmed.

\section{Structural Model}

Following testing the measurement model, structural model analyzes were conducted to test the relationships between latent structures. In this step, the model data fit of the structural equation model, which explains the relationships between dependent and independent variables, was first examined, and then the mediated structural model was tested. Before testing the proposed complete model, firstly the model testing the path between motivation and reading comprehension was constructed. The path diagram of the structural model explaining the effect of motivation on the reading comprehension is presented in Figure 2.

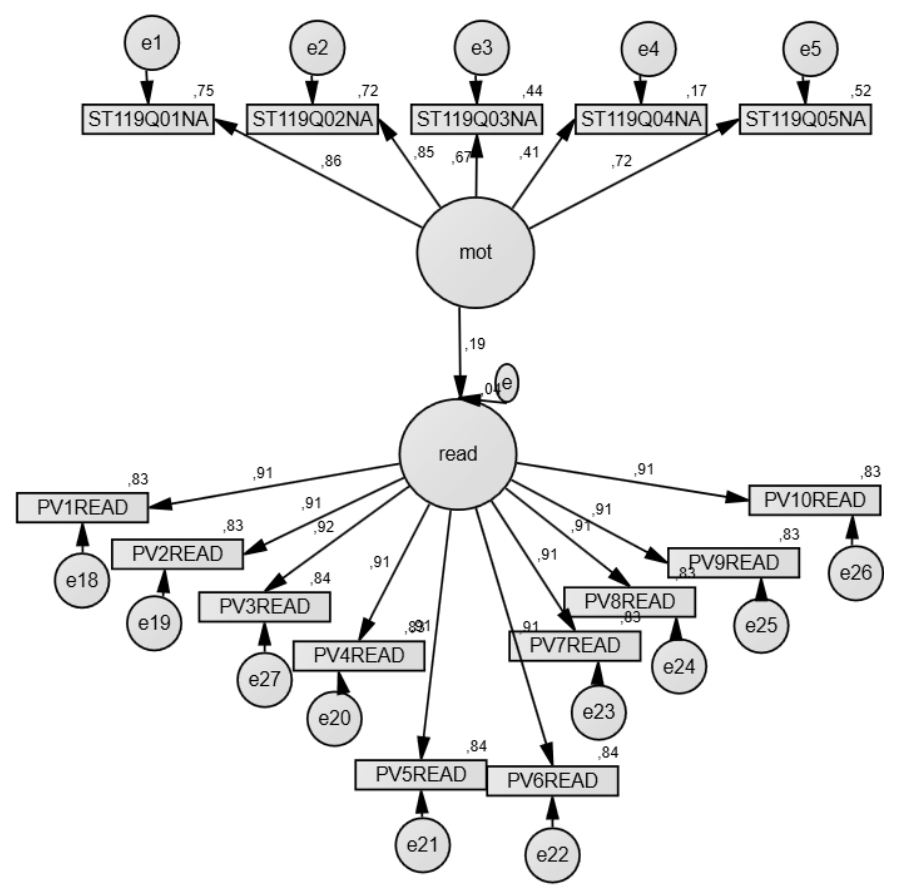

FIGURE 2. The path diagram of the trial model with standardized path coefficients

In Figure 2, it is seen that the model that the standardized path coefficients corresponding relation between motivation and reading comprehension is statistically significant $(\beta=0.193$, $\mathrm{p}<0.05$ ). It can be said that it predicts their behavior positively and significantly reading comprehension. In the second step, all the direct and indirect paths between the variables were applied to the model (Dunkley, \& Blankstein, 2000). The significance levels of the paths were examined as the path diagram in the following figure.

As seen in the Figure 3, the non-significant regression path from test anxiety to tendency to cooperation to test anxiety $(\mathrm{p}=0.893$, Critical Ratio $=0.135)$ was removed from model. With the remaining significant regression paths, the model reconstructed and re-estimated based on the assumption that all the affective characteristics stemmed from "Motivation". Therefore, the variable that reflects the student's motivation levels were the central variable. The relation between the other two affective characteristics and reading comprehension (the exogenous variable of the model) were constructed. Although the goodness of fit indices was within the good fit interval, the suggested modifications were applied. The items whose error terms made covariates and the change in $\chi 2$ were represented in the Table 3. 


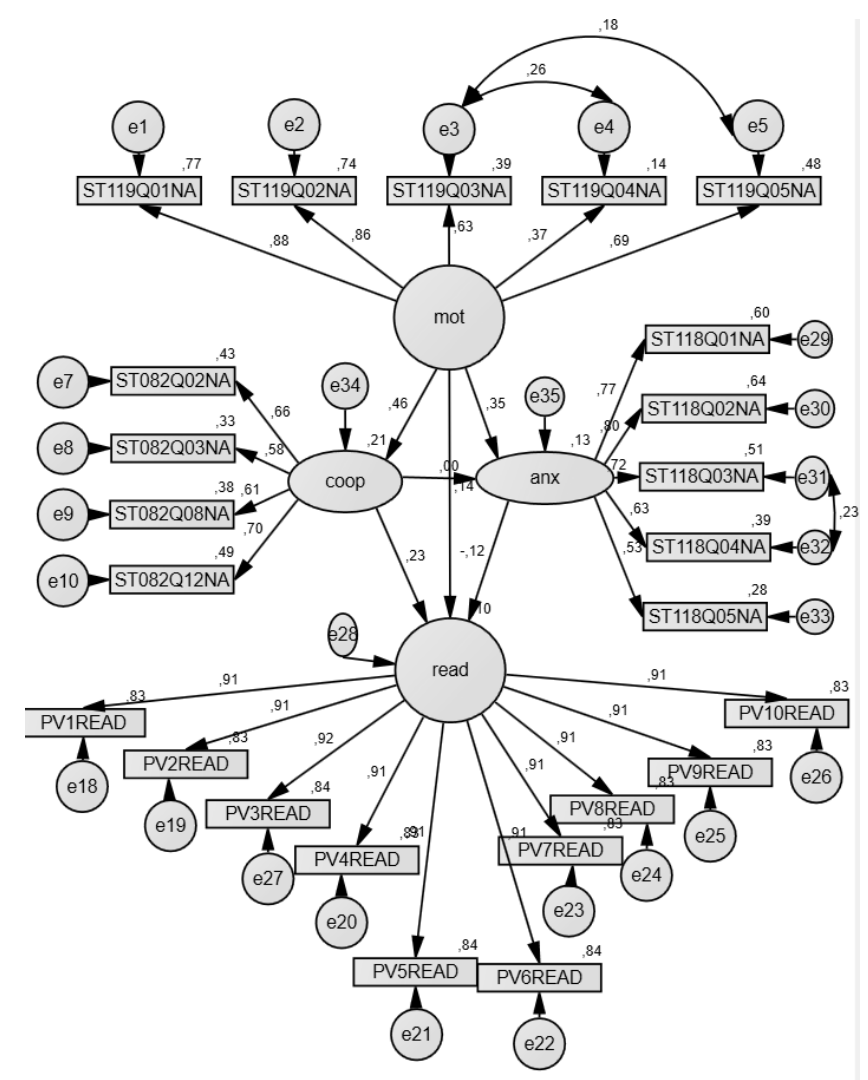

FIGURE 3. The hypothesized model regarding the ability of reading comprehension with standardized path coefficients

Table 3. The Items Whose Error Terms Made Covariates and the Change in $\chi 2$

\begin{tabular}{lcc}
\hline \multicolumn{1}{c}{ Items Whose Error Terms Were Covariated } & $\begin{array}{c}\text { Latent Variable } \\
\text { The Error Term } \\
\text { Belonged }\end{array}$ & The Change in $\boldsymbol{\chi} \mathbf{2}$ \\
\hline $\begin{array}{l}\text { ST119Q03NA/ I want to be the best in whatever I do. } \\
\text { ST119Q04NA/ I see myself as an ambitious person. }\end{array}$ & 108.641 \\
$\begin{array}{l}\text { ST119Q04NA/ I see myself as an ambitious person. } \\
\text { ST119Q05NA/ I want to be one of the best students in my } \\
\text { class. }\end{array}$ & MOTIVATION & 41.740 \\
$\begin{array}{l}\text { ST118Q03NA/ Even if I am well prepared for a test, I feel } \\
\text { very anxious. } \\
\text { ST118Q04NA/ I get very tense when I study for a test. }\end{array}$ & TEST ANXIETY & 37.597 \\
\hline
\end{tabular}

In this study, mediation effects of tendency to cooperation and test anxiety between reading comprehension and motivation were tested for Dunkley and Blankstein's (2000) mediated model. In the literature, this model is also stated as mediated model with four variables. (Şimşek, 2020). Within this study, there exist two mediator variable (test anxiety and tendency to cooperation), one dependent variable (reading comprehension) and independent variable (motivation). In other words, the relation between motivation and reading comprehension was examined under the effect of mediator variables (test anxiety and tendency to cooperation). Baron and Kenny (1986) examine the model as fully and partially mediated. This study is classified as partially mediated model because the level of relation between motivation and reading comprehension decreases when the mediator variables included to the model. The hypothesis of mediation was tested by Bootstrap method. The proposed method is a simple and reliable method which is used to resample in statistics such as statistics and nonparametric estimation problems (Efron, 1979). Hayes (2009) states out that the bootstrap method and experimental M-test provide better results than the Sobel test. The goodness of fit indices 
(RMSEA=0.036, SRMR=0.0458, CFI=0.984, GFI=0.951, NFI=0.976, AGFI=0.941; $\chi_{(244)}^{2}=691.1$, $\mathrm{p}<0.05)$ were above the critical value for a very-good fitted model (Hu, \& Bentler, 1999; Kline, 2005; Tabachnick \& Fidell, 2007). As the other indices reflected the very-well fit, the model was interpreted that it was confirmed by the data.

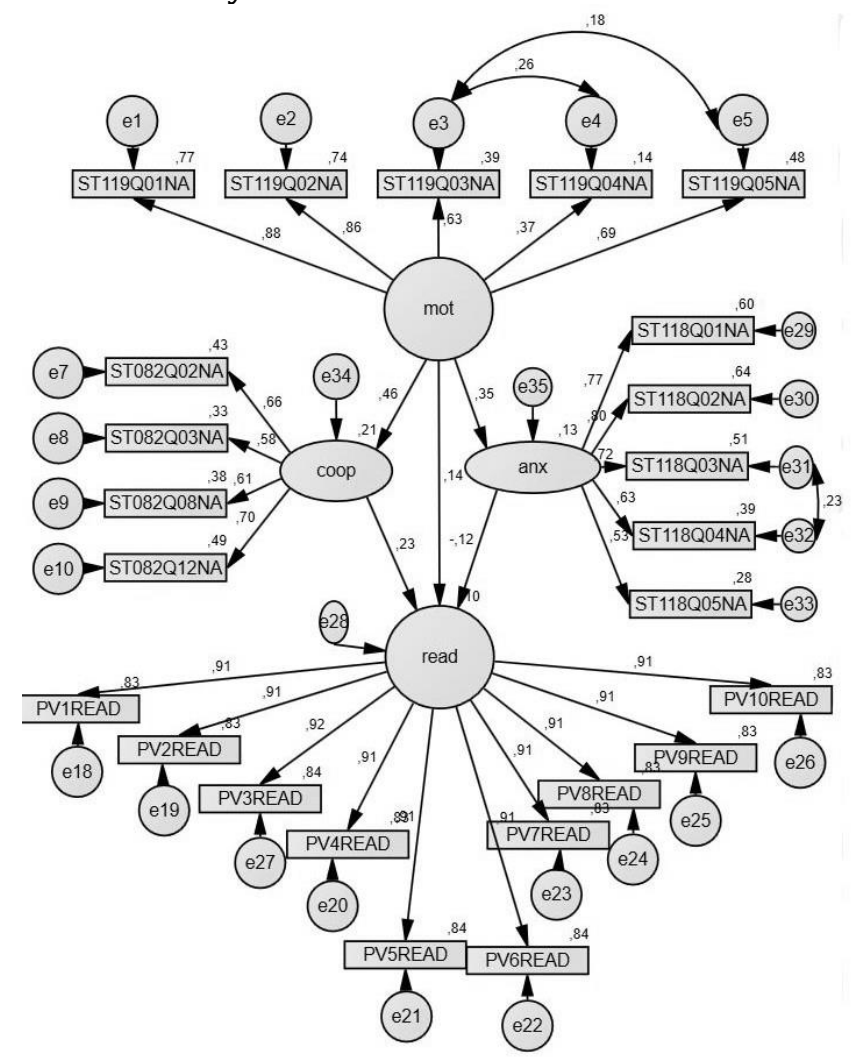

FIGURE 4. Path diagram of the final model regarding reading comprehension with standardized path coefficients

The hypothesis of mediation effect between the motivation and reading comprehension was tested by Bootstrap method. The total indirect (mediated) effect of motivation on reading comprehension is statistically ( $\mathrm{p}=0.004<0.01$, Lower bound=3.072, Upper Bound=15.487). This result supported by the decrease in the regression weight between motivation and reading comprehension $(\beta=0.193, p<0.05)$ after inclusion the tendency to cooperation and test anxiety $(\beta=0.141, p<0.05)$. The following table show the related results about all the significant direct effect.

Table 4. The Regression Results of Significant Direct Effects

\begin{tabular}{lcccc}
\hline Direct Effect & $\begin{array}{c}\text { Unstandardized } \\
\text { Path } \\
\text { Coefficient }\end{array}$ & $\begin{array}{c}\text { Standardized } \\
\text { Path } \\
\text { Coefficient }\end{array}$ & p & Critical Ratio \\
\hline $\begin{array}{l}\text { Cooperation<--- Motivation } \\
\text { Test Anxiety <---Motivation }\end{array}$ & 0.356 & 0.458 & $0.012^{*}$ & 13.778 \\
$\begin{array}{l}\text { Reading Comprehension <--- } \\
\text { Cooperation }\end{array}$ & 0.389 & 0.354 & $0.032^{*}$ & 12.004 \\
$\begin{array}{l}\text { Reading Comprehension <--- } \\
\text { Motivation }\end{array}$ & 16.084 & 0.234 & $0.007^{*}$ & 6.710 \\
$\begin{array}{l}\text { Reading Comprehension<--- } \\
\text { Test Anxiety }\end{array}$ & -12.848 & 0.141 & $0.025^{*}$ & 4.191 \\
\hline
\end{tabular}

${ }^{*} \mathrm{p}<0.05$ 
The table shows the path coefficients and p-values of variables obtained in model. It was observed that the most important latent variable that affected the students' reading comprehension skill was Cooperate $(\beta=0.234, p<0.05$, C.R. $=6.710)$. The second effective characteristic on the students' reading comprehension was motivation. According to the results of the analysis, there is a positive significant direct relation between motivation and reading comprehension level $(\beta=0.141, p<0.05, C . R .=4.191)$. Another finding of the study was the negative direct relation between test anxiety and reading comprehension $(\beta=-0.123, p<0.05$, C.R. $=-4.164)$. As expected, there is a positive relation between motivation and test anxiety $(\gamma=$ $0.354, p<0.0, C . R .=12.004)$. And finally, the results revealed the positive direct relation between motivation and tendency to cooperation $(\gamma=0.458, p<0.05, C . R .=13.778)$. After calculating the total indirect effect, the specific indirect effects were examined.

Table 5. The regression results of testing the indirect effects motivation on reading comprehension via mediator variables

\begin{tabular}{lccc|cc}
\hline $\begin{array}{l}\text { The Indirect Effect of Motivation } \\
\text { on Reading Comprehension via }\end{array}$ & $\begin{array}{c}\text { Standardized } \\
\text { Path } \\
\text { Coefficient }\end{array}$ & $\begin{array}{c}\text { Unstandardized } \\
\text { Path Coefficient }\end{array}$ & Lower & Upper & p \\
\hline $\begin{array}{l}\text { Motivation <---Cooperation<--- } \\
\text { Reading Comprehension }\end{array}$ & 0.107 & 12.315 & 8.612 & 17.707 & $0.009^{*}$ \\
$\begin{array}{l}\text { Motivation <---Test Anxiety<--- } \\
\text { Reading Comprehension }\end{array}$ & -0.44 & -5.000 & -7.678 & -2.687 & $0.015^{*}$ \\
\hline *p<0.05 & & &
\end{tabular}

As seen from the table, the indirect effects between motivation on reading comprehension via cooperation $(\mathrm{p}=0.009)$ and test anxiety $(\mathrm{p}=0.01)$ are statistically significant. In the following table, the results of the testing the indirect effects of motivation on reading comprehension via two mediating variables are presented.

\section{DISCUSSION and CONCLUSIONS}

This present study attempted to explore the relationship between students' reading comprehension and some characteristics. As a general result, the study revealed that there is partial mediation effect of tendency to cooperation on relationship between motivation and reading comprehension. Therefore, there was a positive and significant relationship between motivation and reading comprehension. Many studies were conducted to explore the advantages of motivated students. In general, (intrinsically) motivated students are more successful (Anmarkud, \& Braten, 2009; Areepattanamannil, \& Freeman, 2008; Ahmadi, 2017) and their intellectual performance is better (Deci \& Ryan, 1995). Specifically, students with high motivation and interest in reading were expected to have higher levels of reading skill (Taylor, Pearson, Peterson \& Rodriguez, 2003). Especially intrinsic motivation was positively related to reading comprehension (Yıldız \& Akyol, 2011). Therefore, the studies focus on the ways to increase the motivation of reading. The researchers focus on practices that increase students' motivation and indirectly increase their level of reading comprehension. Therefore, they examine the ways of increasing students motivation by simulating task (Guthrie, Wigfield, Humenick, Perencevich, Taboada, \& Barbosa, 2006), text books (Forsten, Grant, \& Hollas, 2003), reading modules (Cuevas, Russell, \& Irving, 2012). All the above studies show that as the students' motivation increase (by any implementation), their reading comprehension level increases too.

There is a significant positive and moderate relation between the tendency to cooperation and reading comprehension. The Cooperate variable was specifically used in PISA 2015 and there was not any study related to its relation to reading comprehension. However, the scale developed by Kouros and Abrami (2006) has a sub-dimension whose items are common with the Cooperate scale in PISA 2015. Therefore, Kouros and Abrami (2006) conducted a study to examine the correlation between students' achievement and their sub-dimensions of attitude toward 
cooperative group work in class. In general, it was found out that there was not a high relation between the students' attitudes and their achievement. Only the quality of the product and process and students' achievement is statistically significant and negatively correlated $(\mathrm{p}<.01, \mathrm{r}=-$ 0.12). In another study, Goddard, Goddard, and Tschannen-Moran (2007) found out that students who were in collaboration with their teachers and friends were more successful. Another finding related to the tendency to cooperation was its significant relation with motivation $(\gamma=0.529$, $\mathrm{p}<0.01$, C.R. $=29.508$ ). This finding was similar to the results of studies conducted earlier. In a study by Guthrie, Hoa, Wigfield, Tonks, Humenick, and Littles (2007), the socialization was examined as a source of reading motivation. The results of the study showed that the students' motivation increased as they interacted with each other. Therefore, the significant relation between motivation and cooperation was corresponded to the findings in the literature. Beyond this significant relationship, the results revealed that the tendency to cooperation had a mediating role on the relationship between motivation and reading comprehension. Wentzel, \& Wigfield (1998) found out that students who like joining a group of learners by completing tasks are likely to become motivated readers intrinsically and have better reading comprehension performance. Similarly, the more social motivation exists, the more effort the students spent to have higher level of achievement in reading (Wentzel, 1996).

It was found out that test anxiety was the least effective factor related to reading comprehension. This finding is supported by the many studies in the literature (DeDeyn, 2011; Derakshan, \& Eysenck, 2009; Salari, \& Moinzade, 2015; Sellers, 2000; Sert, 2010). According to Dusek (1980), many attentional and cognitive processes interfered with effective task performance when test anxiety occurred. Similarly, Zeidner (1998, p.4) stated that "Test-anxious students tend to be easily distracted on an exam, experience difficulty in comprehending relatively simple instructions, and also have difficulty organizing or recalling relevant information during the test". However, in the literature there also exist studies that found out insignificant relation between stated variables (Javanbakht, \& Hadian, 2014). Wood, Hart, Little and Phillips (2016) examined the relation between test anxiety and reading comprehension performance of children at least 9 years old. The results of the study revealed that test anxiety was negatively associated with reading comprehension test performance. Despite this negative relation, other variables such as study skills and motivation also related to student's performance (Dusek, 1980; Salari \& Moinzade, 2015). From a different perspective, Eysenck and Calvo (1992) stated that the task difficulty is also a crucial factor to clarify the relation between the test anxiety and comprehension. In another word, to explain the relationship between reading comprehension and test anxiety, other characteristics should also be taken into consideration. In the study, motivation is taken into consideration for this mean. Beyond this significant and negative relationship, it was found out that the test anxiety had a mediating role between motivation and reading comprehension. The studies in the literature support the combination of motivation and test anxiety is related to the students' performance especially when the stake is high (Horwittz, 2001; Noels, Pelletier, Clement \& Vallerand, 2000). This similar in also for classroom assessment (Hancock, 2001). Another result of the study showed that highly motivated students more concern about the failure in the test than the low motivated students. Similar to this finding, studies indicated that intrinsic motivation, which was undermined in self-perceived autonomy, was negated by socially controlling events, such as evaluation (Harackiewicz, Manderlink, \& Sansone, 1984). For example, being closely watched or surveilled under certain circumstances is linked to performance evaluation and attempts to compel individuals to comply with rules or standards (Lepper, \& Greene, 1975).

According to Philips, Pitcher, Worsham, and Miller (1980), the students with high test anxiety are more motivated to avoid criticism than to gain praise. On the other hand, these results may be explained by the student's target-orientation. Dacanay (2016) found out that $18.7 \%$ of the variance in cognitive test anxiety could be attributed to personality when mediated by goal orientation. Therefore, more extrinsically motivated students were identified as having more conscientious traits and having higher cognitive test anxiety levels. From this perspective, motivation could be defined as the perseverance to reach the target. Similarly, test anxiety could be defined as the concern about failure in a test. As the students become more motivated for 
success, the exam becomes more crucial for them and they would become more anxious during the exam. Cheng, Klinger, Fox, Jin \& Wu (2014) examined the test takers' motivation, test anxiety and test performance across a range of social and educational context in three language tests which were the Canadian Academic English Language Assessment in Canada, the College English Test in the People's Republic of China and the General English Proficiency Test in Taiwan. The findings of the study indicated that motivation and the test anxiety interacted with social contextual and personal factors leading to performance differences across the three testing contexts. The literature supports the combination of motivation and test anxiety is related to the students' performance especially when the stake is high (Horwittz, 2001; Noels, Pelletier, Clement, \& Vallerand, 2000).

The study found out the partially mediating effect of test anxiety and cooperation on the relationship between motivation and reading comprehension. There are statistically significant and positive relationships between motivation, and test anxiety, tendency to cooperation and reading comprehension. There is also statistically significant and negative relationship between reading comprehension and test anxiety. Lastly, there is statistically significant relationship between tendency to cooperation and reading comprehension. These statistically significant relationships support the importance of affective features on the development of reading comprehension skills. Therefore, the designing the school environment in the way that mainly increases students' motivation would be positively effective on students' reading comprehension. Because of the mediating roles, increasing students' motivation would decrease their test anxiety and increase tendency to cooperation. Accordingly, regularly the effects of the curriculum which is presented to students by the Ministry of National Education and its intermediary schools may be researched. Studies that increase students' motivation, encourage them to cooperate and reduce the test anxiety can be done. In this context, seminars can be conducted for teachers and parents by professionals to increase motivation. This study was limited to the variables determined within PISA 2015. Based on the results of this study, it would be suggested to study different affective features for the future researchers. In future researches, the correlation between the different variables comprehension can be examined by using PISA 2018 Turkey sample data. As stated before, reading comprehension is defined as a communication process between the reader and writer; therefore, it is a kind of reconstruction process in the reader's mind. Therefore, examining the other variables as empathy, self-esteem would provide meaningful information and increase the total variance in reading comprehension.

\section{REFERENCES}

Ahmadi, M. R. (2017). The impact of motivation on reading comprehension. International Journal of Research in English Education, 2(1), 1-7.

Akyol, H. (2006). Okuma. A. Kırkkıllıç \& H. Akyol (Ed.), İlköğretimde Türkçe Öğretimi, 15-48, Ankara: Pegem Akademi.

Akyol, H. (2012). Türkçe ilk okuma yazma öğretimi-yeni programa uygun. Ankara: Pegem Akademi.

Anderson, J. C., \& Gerbing, D. W. (1988). Structural equation modeling in practice: A review and recommended two-step approach. Psychological Bulletin, 103(3), 411.

Anderson, R. C. \& Pearson, P.D. (1984). A schema-theoretic view of basic processes in reading. New York: Longman.

Anmarkrud, Ø., \& Bråten, I. (2009). Motivation for reading comprehension. Learning and Individual Differences, 19(2), 252-256.

Arbuckle, J. (1997). Amos users' guide version 3.6. Chicago: Small Waters Corporation.

Areepattamannil, S., \& Freeman, J.G. (2008). Academic achievement, academic selfconcept, and academic motivation of immigrant adolescents in the Greater Toronto Area secondary schools. Journal of Advanced Academics, 19, 700-743.

Aslanoğlu, E. A., \& Kutlu, Ö. (2015). PIRLS 2001 Türkiye verilerine göre 4. sinıf öğrencilerinin okuduğunu anlama becerileriyle ilișkili faktörler. Eğitim Bilimleri Araștırmaları Dergisi, 5(2), 1-18.

Baker, L. \& Wigfield, A. (1999). Dimensions of children's motivation for reading and their relations to reading activity and reading achievement. Reading Research Quarterly, 34, 452-477. 24 May 2020 
retrieved

from

https://pdfs.semanticscholar.org/766b/373db913c56ab2f3c78202bce7cd25572af0.pdf

Baker, L. Afflerbach, P., \& Reinking, D. (2006). Developing engaged reader in school and home communities: an overview. In L. Baker, P. Afflerbach \& D. Reinking (Eds.), Developing engaged readers in school and communities, 13-27. Mahwah, NJ: Erlbaum.

Barker, C., Pistrang, N., \& Elliott, R. (2015). Research methods in clinical psychology: an introduction for students and practitioners (3rd ed.). Oxford, UK: John Wiley \& Sons, Ltd.

Baron, R. M., \& Kenny, D. A. (1986). The moderator-mediator variable distinction in social psychological research: Conceptual, strategic, and statistical considerations. Journal of Personality and Social Psychology, 51, 1173-1182.

Binyazar, A. (2010). Toplum ve edebiyat. Can Yayınları.

Birjandi, P., \& Alemi, M. (2010). The impact of test anxiety on test performance among Iranian EFL learners. BRAIN: Broad Research in Artificial Intelligence and Neuroscience, 1(4), 44-58.

Calvo, M. G., Ramos, P.M., \& Estevez, A. (1992). Test anxiety and comprehension efficiency: The role of prior knowledge and working memory deficits. Anxiety, Stress, and Coping, 5(2), 125-138.

Cheng, L., Klinger, D., Fox, J., Doe, C., Jin, Y., \& Wu, J. (2014). Motivation and test anxiety in test performance across three testing contexts: The CAEL, CET, and GEPT. TESOL Quarterly, 48(2), 300-330.

Cohen, J. (1990). Things i have learned (so far). American Psychologist, 45, 1304-1312. https://doi.org/10.1037/0003-066X.45.12.1304.

Creswell, J. W. (2012). Educational research: Planning, conducting, and evaluating quantitative and qualitative research. Upper Saddle River, NJ: Prentice Hall.

Cuevas, J. A., Russell, R. L., \& Irving, M. A. (2012). An examination of the effect of customized reading modules on diverse secondary students' reading comprehension and motivation. Educational Technology Research and Development, 60(3), 445-467.

Çelik, H. E., \& Yılmaz, V. (2013). LISREL 9.1 ile yapısal eşitlik modellemesi, temel kavramlar-uygulamalarprogramlama. Ankara: Anı Yayıncılık.

Çokluk, Ö., Şekercioğlu, G., \& Büyüköztürk, Ş. (2012). Sosyal bilimler için çok değişkenli istatistik SPSS ve LISREL uygulamaları. Ankara: Pegem Akademi.

Dacanay, A. (2016). A model exploring cognitive test anxiety: personality and goal orientation. (Unpublished doctoral thesis). Ball State University, Graduate School of Educational Psychology, Muncie.

Deci, E.L., \& Ryan, R.M. (1995). Human autonomy: the basis for true self-esteem. In M. Kernis (Ed.), Efficacy, Agency, and Self-esteem, 31-49. New York: Plenum.

DeDeyn, R. (2011). Student identity, writing anxiety and writing performance: A correlational study. (Unpublished master thesis). Colorado State University, Colorado.

Derakshan, N., \& Eysenck, M. W. (2009). Anxiety, processing efficiency, and cognitive performance: New developments from the attentional control theory. European Psychologist, 14(2), 168-176.

Dinçyürek, S. (2004). Üniversite öğrencilerinin empatik becerilerinin çeşitli değişkenler açısından incelenmesi. Marmara Coğrafya Dergisi, 10, 95-116.

Duke, N., \& Carlisle, J. F. (2011). Comprehension development. In M. L. Kamil, P. D. Pearson, P. A. Afflerbach, \& E. B. Moje (Eds.). Handbook of reading research (Vol. 4, pp. 199-228). New York: Routledge.

Dunkley, D. M., \& Blankstein, K. R. (2000). Self-critical perfectionism, coping, hassles, and current distress: A structural equation modeling approach. Cognitive Therapy and Research, 24(6), 713-730.

Dusek, J. B. (1980). The development of test anxiety in children. In I. G. Sarason (Ed.). Test anxiety, Theory, research, and applications (pp. 87-110). Hillsdale, NJ: Lawrence Erlbaum Associates.

Dweck, C. S. (1975). The role of expectations and attributions in the alleviation of learned helplessness. Journal of Personality and Social Psychology, 31, 674-685.

Efron, B. (1979). Bootstrap methods: another look at the jackknife. The Annals of Statistics, 7(1), 1-26.

Eysenck, M. W., \& Calvo, M. G. (1992). Anxiety and performance: The processing efficiency theory. Cognition \& Emotion, 6(6), 409-434.

Forsten, C., Grant, J., \& Hollas, B. (2003). differentiating textbooks: strategies to improve student comprehension \& motivation. Peterborough: Crystal Springs Books,

Fraenkel, J. Wallen, N., \& Hyun, H. (2012). How to design and evaluate research in education. New York: McGraw-Hill.

Goddard, Y. L., Goddard, R. D., \& Tschannen-Moran, M. (2007). A theoretical and empirical investigation of teacher collaboration for school improvement and student achievement in public elementary schools. Teachers College Record, 109(4), 877-896.

Göktürk, A. (1989). Sözün ötesi: Yazılar. Ankara: İnkılâp Yayınları.

Göktürk, A. (2002). Okuma uğraşı. İstanbul: Yapı Kredi Yayınları. 
Grabe, W., \& Stoller, F. (2001). Reading for academic purposes: Guidelines for the ESL/EFL teacher. In M. Celce-Murcia (Ed.), Teaching English as a Second or Foreign Language (3rd ed., 187-204). USA: Heinle \& Heinle.

Guthrie, (2004). Classroom Contexts for Engaged Reading: An Overview. In J. T. Guthrie, A.E. Wigfield \& K. C. Perencevich (Eds.). Motivating reading comprehension: Concept-oriented reading instruction., 124. Hillsdale, NJ: Lawrence Erlbaum Associates Publishers.

Guthrie, J. T., Hoa, A. W., Wigfield, A., Tonks, S. M., Humenick, N. M., \& Littles, E. (2007). Reading motivation and reading comprehension growth in the later elementary years. Contemporary Educational Psychology, 32(3), 282-313.

Guthrie, J. T., Wigfield, A., Humenick, N. M., Perencevich, K. C., Taboada, A., \& Barbosa, P. (2006). Influences of stimulating tasks on reading motivation and comprehension. The Journal of Educational Research, 99(4), 232-246.

Hair Jr, J. F., Black, W. C., Babin, B. J., Anderson, R. E., \& Tatham, R. L. (2010). SEM: An introduction. Multivariate Data Analysis: A Global Perspective, 5(6), 629-686.

Hancock, D. R. (2001). Effects of test anxiety and evaluative threat on students' achievement and motivation. The Journal of Educational Research, 94(5), 284-290.

Harackiewicz, J. M., Manderlink, G., \& Sansone, C. (1984). Rewarding pinball wizardry: Effects of evaluation and cue value on intrinsic interest. Journal of Personality and Social Psychology, 47(2), 287.

Hayes A. F. (2009). Beyond baron and kenny: statistical mediation analysis in the new millenium. Communication Monographs, 76(4), 408-420.

Horwitz, E. K. (2001). Language anxiety and achievement. Annual Review of Applied Linguistics, 21, 112126. doi:10.1017/S0267190501000071.

Horwitz, E. K., \& Young, D. J. (1991). Language anxiety: From theory and research to classroom implications. U.S.A.: Pearson College Div.

Hu, L.T. and Bentler, P.M. (1999). Cutoff criteria for fit indexes in covariance structure analysis: conventional criteria versus new alternatives. Structural Equation Modeling, 6 (1), 1-55.

Javanbakht, N. \& Hadian, M. (2014). The effects of test anxiety on learners' reading test performance. Procedia-Social and Behavioral Sciences, 98, 775-783.

Johnson, D.W., \& Johnson, R.T. (1999). Making cooperative learning work. Theory into Practice, 38 (2), 67 73.

Katrancl, M. \& Kuşdemir, Y. (2016). Anxiety and comprehension in reading: I can not find the main idea, my teacher!, Education and Science, 41(183), 251-266.

Kline, R. B. (2005). Principles and practice of structural equation modeling. New York: Guilford.

Kouros C, \& Abrami PC (2006). How do students really feel about working in small groups? The role of student attitudes and behaviors in cooperative classroom settings. Paper presented at The American Educational Research Association (AERA) Annual Meeting, April 2006, San Fransisco, USA.

Kintsch, E., \& Kintsch, W. (2005). Comprehension. In S.G. Paris, A.S. Stahl (Eds.) Children's reading comprehension and assessment, 89-110. New Jersey: Lawrence Erlbaum Associates.

Kutlu, Ö. (2004). Türkiye'de demokrasi anlayışının gelişmesini sağlayacak bir yol: okuduğunu anlama becerilerinin geliştirilmesi. Uluslararası Demokrasi Eğitimi Sempozyumu'nda sunulan sözlü bildiri, Çanakkale, Türkiye.

Kutlu, Ö., Altıntaş, Ö., Özyeter, N. T., Alpayar, Ç., \& Kula Kartal, S. (2019). Okuduğunu anlama becerisinin ölçülmesi ve değerlendirilmesi. Ankara: Ankara Üniversitesi Ölçme ve Değerlendirme Uygulama ve Araştırma Merkezi Yayınları.

Lepper, M. R., \& Greene, D. (1975). Turning play into work: Effects of adult surveillance and extrinsic rewards on children's intrinsic motivation. Journal of Personality and Social Psychology, 31(3), 479486.

Ministry of National Education, Republic of Turkey (MoNE) (2018). Turkish Course Instructional Program: 1st, 2nd, 3rd, 4th, 5th, 6th, 7th, 8th Grades in Elementary and Middle School. 2 May 2020 retrieved from http://mufredat.meb.gov.tr/Dosyalar/20195716392253-02T\%C3\%BCrk\%C3\%A7e\%20\%C3\%96\%C4\%9Fretim\%20Program\%C4\%B1\%202019.pdf

Noels, K. A., Pelletier, L. G., Clement, R., \& Vallerand, R. J. (2000). Why are you learning a second language? Motivational orientations and self-determination theory. Language Learning, 50, 57-86. doi:10.1111/0023-8333.00111.

Nunally, J.C. (1978). Psychometric theory. New York: McGraw-Hill.

OECD, (2017). PISA Technical Report. Retrieved 14 February 2018 from doi: 10.1787/79913c69-en.

Pallant, J. (2013). SPSS survival manual. UK: McGraw-Hill Education. 
Philips, B.N., Pitcher, G.D., Worsham, M.E. \& Miller, S.C. (1980). Test anxiety and school environment. In I.G. Sarason (Ed.), Test anxiety: Theory, research and applications, 327-346: Hillsdale, NJ: Lawrence Erlbaum.

Rand Reading Study Group. (2002). Reading for understanding: toward an R\&D program in reading comprehension. Washington DC: Rand Education.

Rogers, C. R. (1983). Empatik olmak değeri anlaşılmamış bir varoluş şeklidir. (Çev. F. Akkoyun,) Ankara Üniversitesi Ĕ̆itim Bilimleri Fakültesi Dergisi, 16(1), 103-123. (Orijinal yayın tarihi, 1975)

Salari, Z., \& Moinzade, S. N. (2015). The impact of test anxiety on reading comprehension test performance in relation to gender among Iranian EFL learners. Linguistics and Literature Studies, 3(5), 203-212.

Sellers, V. D. (2000). Anxiety and reading comprehension in Spanish as a foreign language. Foreign Language Annals, 33(5), 512-520.

Sert, A. (2010). İlköğretim altıncı sınıf öğrencilerinin okuduğunu anlama becerilerinin bazı değişkenler açısından incelenmesi. (Yayımlanmamıș doktora tezi). Selçuk Üniversitesi, Konya.

Sever, S. (2004). Türkçe öğretimi ve tam öğrenme. Ankara: Anı Yayıncılık.

Şimşek, Ö. F. (2020). Yapısal eşitlik modellemesine giriş: Temel ilkeler ve lisrel uygulamaları. Ankara: Ekinoks Yayıncilık.

Strayer, J., \& Robert, W. (2004). Empathy and observed anger and aggression in five-year-old. Social Development, 13, 1-13. $20 \quad$ May 2020 retrieved from https://www.researchgate.net/publication/227513716

Tabachnick, B. G., \& Fidel, L. S. (2007). Using multivariate statistics. Massachusetts: Allyn \& Bacon, Inc.

Taş, U. E., Arıcı, Ö., Özarkan, H. B., \& Özgürlük, B. (2016). PISA 2015 Ulusal Raporu. Ankara: Milli Eğitim Bakanlı̆̆l.

Tavşancıl, E. (2005). Tutumların ölçülmesi SPSS veri analizi. Ankara: Nobel Yayınları.

Taylor, B. M., Pearson, P. D., Peterson, D. S., \& Rodriguez, M. C. (2003). Reading growth in high-poverty classrooms: The influence of teacher practices that encourage cognitive engagement in literacy learning. Elementary School Journal, 104, 3-28.

Thomson, S., Hillman, K., \& De Bortoli, L. (2013). A teacher's guide to PISA reading literacy. Victoria: ACER Press.

Ünalan, Ș. (2006). Türkçe Öğretimi. Ankara: Nobel Akademik Yayıncılık.

Wang, J. H., \& Guthıre, T. J. (2004). Modeling The Effect Of İtrinsic Motivation, Extrinsic Motivation, Amount Of Reading and Past Reading Achievement on Text Comprehension Between U.S. And Chinese Students. Reading Research Quarterly, 39(2), 162-186. 26 May 2020 retrieved from https://www.researchgate.net/publication/250055459_Modeling_the_Effects_of_Intrinsic_Motiv ation_Extrinsic_Motivation_Amount_of_Reading_and_Past_Reading_Achievement_on_Text_Compr ehension_Between_US_and_Chinese_Students

Wentzel, K. R. (1996). Social and academic motivation in middle school: Concurrent and long-term relations to academic effort. The Journal of Early Adolescence, 16, 390-406.

Wentzel, K. R., \& Wigfield, A. (1998). Academic and social motivational influences on students' academic performance. Educational Psychology Review, 10, 155-175.

Wigfield, A., \& Guthrie, J.T. (1997). Relations of children's motivation for reading to the amount and breadth of their reading. Journal of Educational Psychology, 89(3), 420-432. 26 May 2020 retrieved from http://www.cori.umd.edu/research-publications/1997-wigfield-guthrie.pdf

Wigfield, A., Guthrie, J. T., Tonks, S., \& Perencevich, K. C. (2004). Children's motivation for reading: Domain specificity and instructional influences. The Journal of Educational Research, 97(6), 299-310.

Wood, S. G., Hart, S. A., Little, C. W., \& Phillips, B. M. (2016). Test anxiety and a high-stakes standardized reading comprehension test: A behavioral genetics perspective. Merrill-Palmer quarterly (Wayne State University. Press), 62(3), 233.

Yamaç, A., \& Sezgin, Z. Ç. (2018). The relationship among fourth-graders' reading anxiety, reading fluency, reading motivation, and reading comprehension, Education, and Science, 43(194), 225-243.

Yıldız, M., \& Akyol, H. (2011). İlköğretim 5. sınıf öğrencilerinin okuduğunu anlama, okuma motivasyonu ve okuma alıșkanlığı arasındaki ilișki. Gazi Eğitim Fakültesi Dergisi, 31 (3), 793-815.

Yurttaş, S. (2018). Benlik saygısı, sınav kaygısı, tükenmişlik ve cinsiyetin 8. sinıf öğrencilerinin akademik başarısını yordamasında otomatik düşüncelerin aracı rolü. (Yayımlanmamış yüksek lisans tezi). Gazi Osman Paşa Üniversitesi, Tokat.

Zeidner, M. (1998). Test anxiety: The state of the art. New York: Plenum Press. 